\title{
Gender Ideology of Translators Implicated in Feminist Novels
}

\author{
Fateme Mohammadi \\ Kharazmi University. Tehran, Iran
}

Received: 20-04-2014

doi:10.7575/aiac.ijclts.v.2n.3p.36
Accepted: 25-05- 2014

Published: 01-07- 2014

\begin{abstract}
This study compares two Persian translations of Virginia Woolf `s Mrs Dalloway(1925); one done by a male (Darush) and one by a female translator(Taheri). Regarding Farzaneh Farahzad`s translation criticism based on CDA and Farzan Sojoodi's stratificational semiotics, this study analyzed the effect of gender ideology on lexical choices by the two translators. The manipulated words and phrases were analyzed as the reflection of fundamental theories based on the cognitive and personality psychology. It was revealed that translators are definitely affected by their cognitive and mental psychological areas in making gendered lexical choices. Furthermore, almost all the manipulated selected words were done by the male translator. Statistical data, on the other hand, revealed a difference between positive and negative gender values in which the negative choices were used more by the male and the positive ones more by the female translator.
\end{abstract}

Keywords: CDA, feminism, gender, ideology, semiotics

\section{Introduction}

Translation criticism should not be a mere identification of errors, an intuitive or highly subjective appraisal judging translations as 'good', 'bad', 'faithful' without qualifying these adjectives. Criticism should take into account the presence of ideology in translation. The exercise of ideology in translation is as old as translation itself, but their relationship is complex and multifaceted. The concept of ideology and its importance, by the translation studies scholars is realized as a set of ideas which organize our lives and help us understand relationship to our environment. Translation no longer seen as a bridge between cultures and cultural entities but as a creative cultural activity and languages are seen as a part of the process in which identities are formed:

Critical discourse analysis (CDA) assumes that all language use is ideological. From this perspective translation as an instance of language use, is an ideological act and the translator, as a user of language is the agent of this ideological act. Farahzad (2009, p.40).

The field of analytical psychology in translation gender studies opens up a new view of language, exposing how it is used by the dominating patriarchal structures to uphold masculine defining powers in society so that, it can reveal the translator identity as one of the factors which impacts the work of translation. The issue of gender ideology as an important analytical category arose in the late of 1960 and the early of 1970 in North America and Western Europe. Feminists began to bring into consideration the socio- cultural processes that have determined women's inferior status in society. Feminist translation scholars maintain that gender has an important role in the act of writing and translating, the writer and critic. They seek the answer to the question, to what extend gender consciously or unconsciously may affect the translator's translation.

In the 1990s translation studies saw a renewed interest in the analysis of gender and ideology in relation to, and interacting with, translation as theory and practice. Simon presented an extensive study of translation influenced by feminist thought, investigated gender issues in translation, and explored the ways in which women translators have been cultural mediators for centuries, creating "new lines of cultural communication" (Simon 1996: viii); likewise, von Flotow researched practices of feminist translation, from the processes of 'gendered translation' to the translation of ideologically hostile texts, as well as the recovery of 'lost' women translators of the past. Their studies, among those of many other scholars, explored translation(s) operating within language and power. The fertile discussions initiated by the interfacing of translation, gender, and ideology has opened up new perspectives and further research needs to be done and gaps must still be filled. One of the most interesting and thought-provoking questions to offer scope for further research is that of how the ideological beliefs and gender differences of translators affect translation as a process and product.

Regarding specific genres like feminist ones, translators unconsciously make use of psychological properties and exert different linguistic features to render the hidden messages and statements. Adeleh Boostan (2011) in 'Gender Ideology of Translators Implicated in Their Translations of Virginia Woolf's Novels' has focused on the role of translators in cultural communications and emphasized on the translator identity as one of the factors which impacts the work of translation. That study has examined the role of gender in choosing grammatical structures. 
This study tried to represent the indications of a translator's gender in his/ her translation too, so the study located in the area of translation criticism to see whether lexical choices in translations of Virginia Woolf's novels implicate any significant ideological consideration.

\section{Method}

\subsection{The Procedure}

This qualitative- quantitative comparative research adopted Farahzad's model (2009) of translation criticism, which is inspired by critical discourse analysis, and Sojoodi`s stratificational semiotics (1389) (textual layers interrelation) as its frameworks. Since in Farahzads`s model there is no explanation for performing and adapting ideological lexical choices in a study, and for lexical choices need interpretation and perceiving their relationship between text, co-text, context and cultural symbols, Sojoodi`s stratificational semiotics theory seemed crucial to adapt as a complementary framework. The researcher examined the source text and their translated counterparts to determine the role of ideology in translation and to show whether the gender ideology of translator could be represented in his/ her choices of words.

\subsection{The Selected Text of the Study}

The selected text of this research was one of Virginia Woolf"s novels and its translations into Persian; two translations for "Mrs Dalloway" novel by Virginia Woolf in English have been done in Persian by Parviz Darush (1362) and Farzane Taheri (1389). As this research was considering gender ideology on translation, one female and one male translator for the same text were selected. The researcher chose this text especially suitable for feminist critical discourse analysis because following the theory of social construction which states that everything, even personal identity is influenced and formed by interactions with members in one's society. This means that if a woman writer had never been exposed to feminism, it would not be a part of her identity, and therefore, not evident in her writing. While literature offered an escape to women writers, progressive feminist ideas were not always present.

Woolf is one of the greatest writers whose works reflect her philosophy of life and identification of women. She grew up with an intense interest in the feminist question, and her novels hold the key to the meaning of life and the position of women. In her writing, Woolf makes a sifting appraisal of women's problem, their peculiar dilemmas and conditioning in the traditional Victorian society, Woolf was the most vociferous and vehement on feminist issues such as subjectivity, class, sexuality and culture. Woolf believed that it is a part of the occupation of women writers to destroy the patriarchal structures. Woolf strived to give women female identity. In Woolf's strife to set the woman away from the patriarchal society, she called women to re-write the history of women through female eyes and talk about themselves and their experiences truthfully.

\subsection{Data Collection}

Since this study is both qualitative and quantitative, two kinds of data collection were adapted; first the words and phrases which have the potential of enjoying the gender ideological issues were determined. Then the words group was split for quantitative and qualitative methods of research respectively as it follows: the ones which had a considerable frequency were put aside. At the end, three words in English with basically the same meaning but different ways of expression in translations were chosen and analyzed via Chi-square statistical method to see the degree of positive/negative ideological difference between male and female translation texts.

On the other hand, the words which were manipulated either by male or female translator, so that a change of ideological meaning would seem between both the original text and the translation counterparts and, between the two translations. Finally, eleven most interesting words and phrases were adopted as ideologically different from gender perspective.

\subsection{Qualitative Data Processing and Analysis}

First, regarding the qualitative method and the first research question, by applying Farahzad's CDA model of translation criticism and Sojoodi's stratificational semiotics, personality psychology and cognitive psychology seemed to be the best methods for data analysis in order to see whether translators have different lexical choices in this case study.

The pivotal focus in this study was gender ideology, and personality psychology fundamental keys are theories which reflect the reasons of ideological differences. These fundamental keys are as follows:
1. Free Association
2. Archetype
3. Schema
4. Stereotype

Besides these analytical keys the points are also analyzable through cognitive psychology. In other words, the translators might choose words or phrases as a result of their lack of knowledge regardless of analytical psychology. Therefore, the analytical key in cognitive psychology is as follows:

1. Knowledge

The manipulated words were examined to see lexical choices which reflect fundamental theories based on personality psychology if they have not been chosen due to lack of knowledge.

Human behavior arises from two psychological parallel areas. The first one is the cognitive system involving sensory system, nerve system and the brain which includes memory, abstract thought, fantasy, experiences and thoughts. The second area is mental system including feelings and emotions. 
It should be mentioned that the degree of mental complexity depends on the biological and mental experiences after birthday; furthermore, the mental system impresses cognitive system and determines the way it is. As a result what arises as behavior is due to the way these two systems effect upon one another. It is also worth mentioning that in order to find out why male and female translators have different lexical choices, personality psychology and cognitive psychology seems to be a useful analysis method for this kind of data because gender ideology directly arises due to gender behavior which is impressed by the mental area.

\subsection{Quantitative Data Processing and Analysis}

Second, regarding the quantitative method the best statistical methods seemed to be Chi-Square method to be able to answer the research question to see whether male and female translators implicate any significant ideological consideration. The researcher considered the words and phrases as non-parametric dependent variables and gave the words positive or negative values and calculated them in SPSS software.

\section{Results}

\subsection{Data Analysis One}

Through comparing the two translations some basically different ideological gendered lexical choices were observed. Not only some lexical choices seem odd and deviant from normal language use such as /dooshizegie mahfooz/,/madaranegi/,/loole lab sorkh koni/, but also they have been manipulated as a result of the male and female translator's different gender ideologies according to their different personality psychological factors (free association, archetype, schema and stereotype) anddifferent cognitive systems.

Table1. Collected data for qualitative data analysis

\begin{tabular}{|c|c|c|c|c|}
\hline number & Origin & Male Translator & Female Translator & $\begin{array}{c}\text { Neutral } \\
\text { Suggested } \\
\text { Translation }\end{array}$ \\
\hline 1 & women's ailments & $\begin{array}{c}\text { /rænjurihaye zanan/ } \\
\text { p.13)( }\end{array}$ & $\begin{array}{l}\text { /bimarihaye } \\
\text { zænan/)p.53( }\end{array}$ & $\begin{array}{l}\text { /bimarihaye } \\
\text { zænane/ }\end{array}$ \\
\hline 2 & housemaids & $\begin{array}{c}\text { /doxtarane } \\
\text { xedmatkar/ (p.23) }\end{array}$ & /mostaxdeme/ (p.64) & $\begin{array}{c}\text { /zænane } \\
\text { xedmatkar/ }\end{array}$ \\
\hline 3 & cowardly & $\begin{array}{l}\text { /mærdane næbud/ } \\
\text { (p.27) }\end{array}$ & /bozdelane bud/ (p.68) & /bi shahamati/ \\
\hline 4 & virginity & $\begin{array}{c}\text { /dushizegie } \\
\text { mæhfuz/(p.36) }\end{array}$ & /bekarat/ (p.79) & /bakeregi/ \\
\hline 5 & love affairs & /eshq baziha/(p.51) & $\begin{array}{l}\text { /majarahaye asheqane/ } \\
\text { (p.93) }\end{array}$ & $\begin{array}{c}\text { moravedate } \\
\text { asheqane }\end{array}$ \\
\hline 6 & stick of rouge & $\begin{array}{l}\text { /lule læb sorx koni/ } \\
\text { (p.83) }\end{array}$ & /roje læb/ (p.128) & /roj/ \\
\hline 7 & powder-puff & $\begin{array}{l}\text { /gærde sefid zæni/ } \\
\text { (p.83) }\end{array}$ & $/$ pudr/ (p.128) & /pudr/ \\
\hline 8 & Making up & $\begin{array}{l}\text { /?arayesh kærdan/ } \\
\text { (p.83) }\end{array}$ & $\begin{array}{c}\text { /bæzæk konænd/ } \\
\text { (p.128) }\end{array}$ & $\begin{array}{c}\text { /xod ra } \\
\text { biyarayænd/ }\end{array}$ \\
\hline 9 & $\begin{array}{c}\text { astonishing accesses of } \\
\text { emotion }\end{array}$ & $\begin{array}{c}\text { /bruze shærm ?avære } \\
\text { ?ehsasat/ (p.92) }\end{array}$ & $\begin{array}{l}\text { /bruze zæxayere } \\
\text { ?ævatefe heiratængiz/ } \\
\text { (p.137) }\end{array}$ & $\begin{array}{c}\text { /tæjaliye } \\
\text { heyræt } \\
\text { ?angize } \\
\text { ?ehsasate } \\
\text { penhan/ }\end{array}$ \\
\hline 10 & dull women & $\begin{array}{l}\text { /zæne pæxme/ } \\
\text { (p.134) }\end{array}$ & $\begin{array}{l}\text { /zænane mælal avar/ } \\
\text { (p.182) }\end{array}$ & $\begin{array}{l}\text { /zænane } \\
\text { mæmuli/ }\end{array}$ \\
\hline 11 & unmaternal & $\begin{array}{c}\text { /?ehsase mædari } \\
\text { nædashtæn/(p.216) }\end{array}$ & $\begin{array}{l}\text { /?ari ?æz madaranegi } \\
\text { budæn/ (p.269) }\end{array}$ & $\begin{array}{c}\text { /?æz letafæte } \\
\text { mædarane } \\
\text { bibæhre } \\
\text { budæn/ }\end{array}$ \\
\hline
\end{tabular}

Example 3: cowardly

$>\quad[\ldots]$ And it was cowardly for a man to say he would kill himself,( Woolf, 1925, p.17)

1. /va inke yek mard beguyad khodash ra mikoshad bozdelane ast./ Taheri, 1388,p.68)

2. /va in mardane nabud ke yek mard beguyad khodash ra mikoshad./(Darush,p.27)

Necessarily there is no relationship between being a woman or man and being coward, but it seems that for the male translator being coward is equal to not being a man. And committing a suicide for the female translator is an inferior action for men by having a negative choice of /bozdelane/ while a more normal and neutral replace could be /bishæhamæti/.The opposition between the two shows a gender provocation in both cognitive and mental areas. For the 
female translator culturally and psychologically knows a man powerful and what she expects a man is brevity and ability, so committing a suicide is in opposition to what she believes.

Example 9: astonishing accesses of emotion

$>$ But then these astonishing accesses of emotion — bursting into tears this morning, what was all that about?( Woolf, 1925, p.57)

1. /væ ba?d in zaxyere heyratangize ?ehsasat- in hay hay be gerye ?oftadæne ?emruz sobh. Ghazie che bud?/Taheri, 1388,p.137)

2. /?amma pas in bruze shærmavare ?ævatef- in be gerye oftadane ?emruz sobh, ?in digær bæraye che bud?/(Darush, 1362,p.92)

Obviously /shærmavar/ is not equivalent to astonishing; what makes the male translator to translate so might be his own embarrassing feeling when he cries. His gender ideology prevents him from accepting crying as a natural reaction to sadness. Obviously crying not only is not allowed based on his schema for a man characteristics but it is also shameful.

On the other hand, /heyræt ?ængiz/ has also a negative weight of being odd. Considering /shegeft ? ængiz/ as another suggested translation which has a positive meaning, it could be said that she does not expect men to cry so without his willing.

Although both translators have negative choices, the male's one is considerably more negative according to his advocative reaction based on his cognitive system and schemata. By comparing and analyzing the lexical choices by the male and female translators and discovering the ideological gendered motivations and impact of cognitive and mental areas on them, it was clear that translators definitely make a lexical choice according to their mental and cognitive psychological areas, that is they are influenced unconsciously by gender related ideologies dominated in the culture they have grown up. Further, almost all manipulated selected words and phrases have been done by the male translator so that, the words implies meaning beyond the original ones.

Table 2. Data collected for quantitative data analysis

\begin{tabular}{|c|c|c|c|c|}
\hline oWord & $\begin{array}{l}\text { Male'observed } \\
\text { ofrequency }\end{array}$ & $\begin{array}{l}\text { Female'observed } \\
\text { ofrequency }\end{array}$ & Totalnumber & oDegree \\
\hline lezdevai kserdan//R & र्रा1 & प्र30 & $\overline{8} 41$ & Positiver \\
\hline - $/$ gereffen/ & $\overline{2} 2$ & 90 & $\overline{82}$ & Negatives \\
\hline 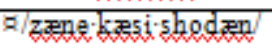 & $\overline{89}$ & 90 & 89 & R Negative \\
\hline प्र/? Prusilkardan/ & प्र० & $\overline{83}$ & प्र3 & QPPositive \\
\hline - $/$ shohrer terdan & 84 & 94 & प्र8 & - Negative \\
\hline $\bar{Q}($ wife $) / z$ nn & $\overline{2} 23$ & $\overline{82}$ & 825 & Q Negative \\
\hline ( & $\overline{82}$ & 94 & प्र6 & QPositive \\
\hline - $/ 5$ hohrer/ & प्रा1 & प्रा0 & प्र21 & - Negative \\
\hline प्र(husband)/hamsær) & व्रा & 90 & व्रा & QRositive \\
\hline oSum & प्र63 & 853 & व्रा16 & 8 \\
\hline
\end{tabular}

\subsection{Data analysis two}

The data collected based on repetition of some words by the male and female translator which seemed ideologically meaningful, regardless of the proto-text. Some words repeated more by the male translator and some by the female one, some have been used by just the male and some just by the female translator and some have been used equally between the two.

Table 3.There is a significant difference between gendered values (positive/ negative) lexical choices.

Chi-Square Tests

\begin{tabular}{|c|c|c|c|c|c|}
\hline & Value & $\mathrm{df}$ & $\begin{array}{c}\text { Asymp. Sig. } \\
\text { (2-sided) }\end{array}$ & $\begin{array}{l}\text { Exact Sig. } \\
\text { (2-sided) }\end{array}$ & $\begin{array}{l}\text { Exact Sig. } \\
\text { (1-sided) }\end{array}$ \\
\hline Pearson Chi-Square & $26.461^{b}$ & 1 & .000 & \multirow{6}{*}{.000} & \multirow{6}{*}{.000} \\
\hline Continuity Correction a & 24.565 & 1 & .000 & & \\
\hline Likelihood Ratio & 27.453 & 1 & .000 & & \\
\hline Fisher's Exact Test & & & & & \\
\hline $\begin{array}{l}\text { Linear-by-Linear } \\
\text { Association }\end{array}$ & 26.233 & 1 & .000 & & \\
\hline $\mathrm{N}$ of Valid Cases & 116 & & & & \\
\hline
\end{tabular}

a. Computed only for a $2 \times 2$ table

b. 0 cells $(.0 \%)$ have expected count less than 5 . The minimum expected count is 23.30 . 
Table 4. The male translator has made more negative ideological gender lexical choices and the female translator has made more positive ones.

\section{word * gender Crosstabulation}

\begin{tabular}{|c|c|c|c|c|}
\hline & & & & \multirow[b]{2}{*}{ Total } \\
\hline & & male & female & \\
\hline \multirow[t]{2}{*}{ word } & positive & 14 & 37 & 51 \\
\hline & negative & 49 & 16 & 65 \\
\hline Total & & 63 & 53 & 116 \\
\hline
\end{tabular}

Regarding the Chi-square table result, there is a significant difference between the gender values (positive /negative) between the male and female translators. Further, the male translator has made more negative ideological gender lexical choices and the female translator has made more positive ones and $72.54 \%$ of positive choices belong to the female translator and $75.38 \%$ of negative choices belong to the male translator. There was also a significant difference between the gender values (positive /negative) between the male and female translators. That is to say, the null hypothesis is rejected; the male and female translators translate differently based on their ideological attitudes. .Further, the male translator has made more negative ideological gender lexical choices and the female translator has made more positive ones and $72.54 \%$ of positive choices belong to the female translator and $75.38 \%$ of negative choices belong to the male translator.

\section{Discussion}

The female author is deeply involved in her work, because it is often considered a re-shaping of herself, whereas the male author is creating something outside of himself. Feminist criticism has felt the need to emphasize how hard it is for men really to imagine what women experience. A theorist, Judith Kegan Gardiner (1980), bases her theories of gender in literary criticism on differences in life experiences of men and women. She explains further, "In a male dominated society, being a man means not being like a woman. As a result, the behavior considered appropriate to each gender becomes severely restricted and polarized" (p.189).

Many female critics believe that male authors write inadequately from the female perspective. Therefore, it is not surprising that they believe that women are more capable of writing (and translating as a result) from the female perspective. As with male authors, many theorists believe that identity is also very important when discussing female authors.

\section{Conclusions \& Implications}

The process of using language is one of constant language choosing; language does much to shape both who someone is and the ways in which he/she observes or construes the world. This study tried to establish a link between CDA, semiotics, psychology, translation criticism and translation studies. Regarding specific genres like feminist ones, translators unconsciously make use of psychological properties and exert different linguistic features to render the hidden messages and statements. Awareness of sex- related differences in translation calls attention to the way human mind works with and within language. And then, translators need to be aware of the phenomenon manipulation in all its manifestations, to be able to control it, and not to be controlled by it. Indeed, it seems that the only possible answer or suggestion in this case might be the appeal to translator ethics, professionalism and commonsense.

Such a study for a translator implies text-type sensitivity and skopos as well as being aware of conscious and unconscious manipulation in order not to be controlled but control the text and situation. For feminist studies might pave the way for a more objective study of women, because a work done by a woman as a writer (specially a feminist one) is rarely compared with its translation or its film; furthermore, there are little feminist researches with the presence of women directly in the study. Actually, writing and translating are considered the only way that women have expressed their own identity truly in societies. And for a psychologist it might be a more objective and evidential analytic psychology way of discovering men`s attitude versus women`s.

\section{References}

Boostan, A. (2011). Gender Ideology of Translators Implicated in Their Translations of Virginia Woolf s novels, M.A thesis. Tehran: Islamic Azad University, Science and Research Campus.

Darush, P. (1362)./xanume dalovi/Mrs. Dalloway], Tehran: Ravagh publication.

Gardiner, J. K. (1980). On Female Identity and Writing by Women. In Elizabeth Abel(Ed.), Writing and Sexual Difference,. Chicago: The University of Chicago Press.

Farahzad, F. (2009). Translation Criticism: A CDA Approach. Translation Studies, 24, 39-47.

Simons, A. (1996). The problem of narrative 'dialogue'. Translation and reception of Le Journal D'une Femme De Chambre, In G.T. Harris (Ed.), On Translating French Literature and Film (pp. 82-112), Amsterdam and Atlanta: Rodopi. 
Sojoodi, F. (2010). /neshane shenasie layeyi va karborde an dar tahlile matne honari/[Stratificational semiotics and its application in analyzing an artistic work].In F. Sojoodi (Ed.), / ?cemal va ncezcerie neshaneshenasi/[Semiotics: Theory and Practice] (pp.209-230), Tehran: Elm.

Taheri, F. (1388). /xanume d $e$ lovey/[Mrs. Dalloway],Tehran: Nilufar press.

Woolf, V. (1925). Mrs. Dalloway. EBook No.: 0200991h.html, Retrieved September 10, 2011 from http://gutenberg.net.au 